\title{
When first-generation students succeed at university: On the link between social class, academic performance, and performance-avoidance goals ${ }^{1}$
}

\author{
Mickaël Jury ${ }^{1}$, Annique Smeding ${ }^{2}$, Martine Court ${ }^{1}$, Céline Darnon ${ }^{1}$ \\ 1Clermont Université, Université Blaise Pascal, Clermont-Ferrand, France \\ 2 Laboratoire Interuniversitaire de Psychologie : personnalité, cognition et changement social, Université de Savoie Mont \\ Blanc, France
}

\begin{abstract}
Past research has fully documented that at University, social-class background affects one's perception of his or her fitting in within the system. The present paper tests social class and academic performance as predictors of performance-avoidance goal endorsement (i.e., trying to avoid performing poorly) in a psychology university context. We argue that first-generation students are achieving an upward mobility - a process that is costly, especially for those closer to achieving it (i.e., high achievers). In three classroom context studies, students reported their performance-avoidance goals. Their previous academic achievements as well as their parental level of education were examined as predictors of these goals. The results of the three studies demonstrated that the higher their academic level, the more firstgeneration students endorsed performance-avoidance goals compared with continuing-generation students. The results are discussed with regard to the upward mobility process that these students are about to achieve
\end{abstract}

\section{Introduction}

University context is a competitive and selective environment where just trying to avoid failure is not the best strategy or the most optimal goal to pursue to achieve success (Harackiewicz, Barron, Tauer, \& Elliot, 2002). Contrary to other types of achievement goals (i.e., mastery-based and performance approach goals) for which consequences are debated in the literature, research on performanceavoidance goals has led to a large consensus regarding their deleterious effects (Durik, Lovejoy, \& Johnson, 2009; Elliot \& Church, 1997; Elliot \& McGregor, 2001; Elliot \& Murayama, 2008; Elliot, Murayama, \& Pekrun, 2011; Huang, 2012; Hulleman, Schrager, Bodmann, \& Harackiewicz, 2010; Murayama \& Elliot, 2012; Van Yperen, Blaga, \& Postmes, 2014). Despite the negative outcomes associated with performance-avoidance goals, several studies have shown that some students adopt these goals anyway (Smith, Sansone, \& White, 2007; Van Yperen, 2006; Van Yperen, Hamstra, \& Van der Klauw, 2011). The present research examines academic performance and social class as two characteristics potentially associated with performance-avoidance goals adoption.

\section{Performance-avoidance goals}

\section{Definition}

The achievement goal construct was developed in the early 1980s. Several researchers, including Carol Dweck (1986) and John Nicholls (1984), defined two main types of achievement goals that students can pursue in an academic task: mastery goals, where the purpose is to develop competence and task mastery, and performance goals, where the purpose is to demonstrate competence relative to others. Later on, researchers incorporated the approach- avoidance distinction in the conceptualization of achievement goals. Notably, Elliot and McGregor (2001, see also Elliot \& Harackiewicz, 1996) defined four different types of goals. In their model, mastery goals are divided into mastery-approach goals (focus on task-based attainment) and mastery-avoidance goals (avoidance of task-based incompetence),

${ }^{1}$ This paper has been published in Contemporary Educational Psychology in 2015. This is the post-print version. The full reference is available at the end of the manuscript. 
whereas performance goals are divided into performance-approach goals and performance-avoidance goals. Performance-approach goals focus on the attainment of positive outcomes and the demonstration of superiority relative to others whereas performance-avoidance goals focus on avoiding the demonstration of inferior competence.

\section{Performance-avoidance goal endorsement and negative outcomes}

Contrary to mastery and performance-approach goals, which are sometimes associated to positive outcomes and are often debated in the literature (e.g., Brophy, 2005; Harackiewicz, Barron, Pintrich, Elliot, \& Thrash, 2002), the adoption of performance-avoidance goals has been consistently associated with several negative outcomes for university students. For instance, performance-avoidance goals are associated with low intrinsic motivation (Elliot \& Church, 1997), procrastination, perception of tasks as threats (McGregor \& Elliot, 2002), disorganization, surface learning (Elliot \& McGregor, 2001), low feedback seeking (Payne, Youngcourt, \& Beaubien, 2007), and compliant forms of conflict regulation (Sommet et al., 2014). Pekrun, Elliot, and Maier (2006, 2009) also pointed out the link between performance-avoidance goals and negative emotions, like anxiety, hopelessness, and shame. Furthermore, the adoption of performance-avoidance goals negatively predicts academic grades (Darnon, Butera, Mugny, Quiamzade, \& Hulleman, 2009a; Durik et al., 2009; Elliot \& Church, 1997; Elliot \& Murayama, 2008; Huang, 2012; Hulleman et al., 2010; Murayama \& Elliot, 2012; Payne et al., 2007).

Because of the negative consequences associated with performance-avoidance goals, researchers and educators alike agree that these goals should be banned from classrooms. University-level teachers do not promote performance-avoidance goals in their classes, and students are aware that these goals are not optimal for reaching academic success (Darnon, Dompnier, Delmas, Pulfrey, \& Butera, 2009b). Thus, students should not pursue performance-avoidance goals. However, several studies have shown that despite the negative outcomes associated with this construct and teachers' recommendations, some students seem to adopt performance-avoidance goals anyway (Smith et al., 2007; Van Yperen, 2006; Van Yperen et al., 2011). Are some groups of students particularly prone to adopt these goals?

\section{Individual antecedents of performance-avoidance goals}

Several individual, person-focused antecedents of performance-avoidance goals have been reported. For example, fear of failure (Elliot \& Church, 1997; Elliot \& Murayama, 2008), fixed beliefs about intelligence (Dinger \& Dickhäuser, 2013; Payne et al., 2007), and personality characteristics like neuroticism (Bipp, Steinmayr, \& Spinath, 2008; Elliot \& Thrash, 2002; Payne et al., 2007) or avoidance temperament (Elliot et al., 2011; Elliot \& Thrash, 2010) have been identified as antecedents of performance-avoidance goal endorsement.

More importantly, research has highlighted that perceived competence is one of the strongest predictors of performance-avoidance goals among both teenagers and college students (Cury, Da Fonséca, Rufo, \& Sarrazin, 2002; Cury, Elliot, Da Fonseca, \& Moller, 2006; Elliot \& Church, 1997; Pulfrey, Buchs, \& Butera, 2011). For example, Elliot and Church (1997) found that college students with low competence expectancies are first oriented toward the possibility of failure and subsequently tend to adopt performance-avoidance goals (see also Cury et al., 2006). More recently, Pulfrey et al. (2011) confirmed that the higher an individual's perception of his or her competence to succeed in a system, the lower his or her performance-avoidance goal endorsement. Such result supports the findings suggesting that a high level of performance-avoidance goal adoption is often associated with a low level of self-efficacy (Deemer, 2010; Hsieh, Sullivan, \& Guerra, 2007; Payne et al., 2007). Other research has shown that actual academic achievement (e.g., GPA, early exam grade, or SAT scores) is also negatively associated with performance-avoidance goal endorsement (Elliot \& McGregor, 2001; Elliot \& Reis, 2003; Pulfrey et al., 2011; Senko \& Harackiewicz, 2005). Thus, high academic achievers are usually less likely to endorse performance-avoidance goals compared with low achievers. 
In academic contexts, several types of information can be used to infer one's probability of success, including actual level of academic achievement and belonging to groups known to perform well or poorly at a university (Fiske $\&$ Markus, 2012). Indeed, low social-class students suffer from a negative stereotype about their competence (Fiske, 2010; Russell \& Fiske, 2010). Such negative stereotypic expectations for low social-class group members may have led some scholars (Elliot, 1999) to suggest that social class could act as an antecedent of performance-avoidance goal endorsement. Yet surprisingly, social class has thus far not been the object of much attention in the achievement goal field, which is a gap that has been recently highlighted in the literature (Darnon, Dompnier, \& Poortvliet, 2012; Huang, 2012).

Related to this issue, it should be noted that some research has shown that cultural belonging influences students' achievement goals (i.e., Asian Americans are more likely to endorse performance-avoidance goals compared with Anglo Americans; Zusho, Pintrich, \& Cortina, 2005; see also Zusho \& Njoku, 2007). Since different social-class groups have different cultural mindsets (Williams, 2012), studying the influence of social-class on achievement goal endorsement represents another way to contribute to the "culturalization of educational psychology" (Zusho \& Clayton, 2011). The present research aims to test whether social-class, like other cultural belongings, would influence performance-avoidance goal endorsement. However, unlike previous research, we consider that social class is only one part of the story and that its interplay with students' level of academic achievement, given the centrality of this latter variable in performance-avoidance goal endorsement, needs to be consider to obtain a comprehensive picture of this issue (Elliot \& McGregor, 2001; Elliot \& Reis, 2003; Pulfrey et al., 2011; Senko \& Harackiewicz, 2005). The present research therefore examined whether an individual characteristic (i.e., one's level of academic achievement) interacts with social-class position (i.e., one's generational status) to predict psychology students' adoption of performance-avoidance goals.

Social class, academic achievement, and performance-avoidance goals

\section{Generational status as an indicator of social class at university}

Social class influences many life outcomes, including health (Gallo, de Los Monteros, \& Shivpuri, 2009), feeding behaviors (Darmon \& Drewnowski, 2008), and socio-cognitive tendencies (Kraus, Piff, Mendoza-Denton, Rheinschmidt, \& Keltner, 2012), as well as university behaviors and outcomes. In particular, recent interest in the effects of social class at university indicates that first-generation students experience a cultural mismatch in university system, which in turn explains why they perform more poorly compared with continuing-generation students (Stephens, Fryberg, Markus, Johnson, \& Covarrubias, 2012a; Stephens, Townsend, Markus, \& Phillips, 2012c). Moreover, first-generation students have been found to be less confident regarding their college success and their self-efficacy compared with continuing-generation students (Ramos-Sánchez \& Nichols, 2007; Wohn, Ellison, Khan, Fewins-Bliss, \& Gray, 2013). These researches used generational status as an indicator of social class at university. Indeed, generational status is associated with success, academic fit, and responses to threat in university context (Harackiewicz et al., 2014; Stephens et al., 2012a, 2012c; Stephens, Markus, \& Fryberg, 2012b; see also Snibbe \& Markus, 2005). It also outstrips other indicators of status (i.e., occupations or incomes) in predicting life consequences (Liberatos, Link, \& Kelsey, 1988). Therefore, in the present series of studies, as in previous research in the area, generational status will be used to assess students' social class.

\section{First-generation students and expectancies of success at university}

First-generation students, more so than continuing-generation students, doubt their chances of success at university. For several reasons detailed below, they may be more likely than continuing-generation students to endorse performance-avoidance goals. First, social class is highly linked to SAT scores and achievement at university (Organisation for Economic Co-operation and Development, 2012; Sackett, 
Kuncel, Arneson, Cooper, \& Waters, 2009; Sirin, 2005), with high social-class students outperforming their low social-class counterparts. Although academic performance is a multiple-determined outcome, this achievement gap might be related to the fact that universities play an important role in the social reproduction of inequalities between high and low social-class students (Bourdieu, Passeron, \& Nice, 1990). Indeed, despite official intentions to provide equal chances of success to all students, regardless of their social background, universities actually favor high social-class students over low social-class students (see also Delandshere, 2001; Darnon et al., 2012; Duru-Bellat, 2006, for a discussion of this issue). Specifically, as grades are supposed to reflect purely merit, university is particularly likely to justify and reproduce social inequalities between low and high social-class students (Jost, Banaji, \& Nosek, 2004; Van Laar \& Sidanius, 2001) and thus serve dominant groups (Sidanius \& Pratto, 1999). Furthermore, it has been documented that in addition to its educational function, university fulfills a selection function (Darnon et al., 2009b; Dornbusch, Glasgow, \& Lin, 1996) and that practices that serve this selection function (e.g., assessment practices) act more in favor of high social-class than of low social-class individuals (Smeding, Darnon, Souchal, Toczek-Capelle, \& Butera, 2013).

The second reason is related to the fact that as first generation students are underrepresented in comparison with continuing-generation students at university, they may evolve in an "out-group" context (Derks, van Laar, \& Ellemers, 2006; Van Laar, Derks, Ellemers, \& Bleeker, 2010). In an outgroup context, the out-group (i.e., as far as first generation students are concerned, continuinggeneration students) is numerically dominant and members of the dominant group usually outperform members of the dominated group. Such context can threaten first-generation students' social identity and push them to use defensive and protective mechanisms that may influence their well-being, motivation, and performance. For instance, in a series of studies, Derks et al. (2006) manipulated participants' status and demonstrated that in an out-group context, low status participants showed emotions related to the avoidance of failure (agitation) and spent more time on items that could help them diminish failure compared with items useful for increasing success. The authors explained these results by the fact that the out-group context made the dominated group's inferiority salient in the domain and threatened their identity. This salience subsequently led participants to focus on failure avoidance. According to authors, one way to face such a situation is upward mobility (i.e., leaving one's original background to get a better social position).

Third, entering university involves a social identity change (Amiot, Terry, Wirawan, \& Grice, 2010). Indeed, entering a new group, such as group of college students, requires many psychological changes for the individual (e.g., appropriation of new norms, modification of the self-concept). For continuinggeneration students, parental transmission can facilitate this process. However, as first-generation students' parents did not go to college, they have limited knowledge of college norms and culture. Thus, contrary to continuing-generation students, first-generation students cannot rely on their parents to cope with this identity change (Jenkins, Belanger, Connally, Boals, \& Durón, 2013).

Fourth, in relation to identity change, first-generation students face an upward mobility when entering university. Although this process can represent a viable outcome, it can also present challenges (Jetten, Iyer, Tsivrikos, \& Young, 2008; Johnson, Richeson, \& Finkel, 2011; Lee \& Kramer, 2013; Ostrove \& Long, 2007; Reay, Crozier, \& Clayton, 2009). Indeed, Jetten et al. (2008) demonstrated that low socialclass students experience a feeling of incompatibility within university system, which impairs their identification with university, and may negatively influence their well-being (Iyer, Jetten, Tsivrikos, Postmes, \& Haslam, 2009). In the same vein, university culture is more likely to match the values of continuing-generation students (i.e., values of independence) compared with those of first-generation students (i.e., values of interdependence, Stephens et al., 2012a, 2012b, 2012c). This "cultural mismatch" leads first-generation students to experience an aversive psychological state characterized by negative emotions and a superior secretion of cortisol, as a biological response to stressful situations (Stephens et al., 2012c). Taken together, research has indicated that the incompatibility that firstgeneration students might experience at university results in several negative consequences, which have the potential to jeopardize the upward mobility process and leave room for strategies focused on failure avoidance. 
Still other research has identified situations in which dominated people show incompatibilities with a situation's expectations. For example, Guinote (2007a, 2007c, 2008; see also Slabu \& Guinote, 2010) found that dominated people had more difficulties responding in an expectancy-consistent way compared with dominant people. They are less able to focus on a target and ignore distracting information (Guinote, 2007b). In general, they have more difficulties inhibiting the processing of irrelevant information and increasing the processing of relevant information (Guinote, 2008). Such interpretation is consistent with the idea that individuals from dominated groups sometimes tend to behave in ways that are consistent with the negative stereotype about their group, which can further justify their status of subordinate and thus contribute to maintaining the status quo (Van Laar \& Sidanius, 2001).

Finally, some research has shown that a "stereotype threat" is likely to occur in university contexts when a negative stereotype about low social-class students' expected underperformance is made relevant (Croizet \& Claire, 1998; Croizet, Désert, Dutrévis, \& Leyens, 2001; Spencer \& Castano, 2007). Indeed, in such contexts, low social-class students feel threatened to confirm the negative stereotype about their own group, which can in turn decrease their performances. Interestingly, some authors have recently linked stereotype threat research to achievement goal research and demonstrated that under stereotype threat, members of stigmatized groups focus on avoidance strategies. Raising their level of performanceavoidance goals seems to regulate this feeling (Brodish \& Devine, 2009; Chalabaev, Sarrazin, Stone, \& Cury, 2008; Ryan \& Ryan, 2005; Smith, 2004). This line of research did not compare first-generation students with continuing-generation students. However, it suggests that low status individuals may endorse avoidance strategies and, more specifically, performance-avoidance goals in identitythreatening situations.

\section{The joint role of academic achievement and social class}

Although past research has suggested that in university contexts first-generation students are particularly likely to adopt avoidance strategies, including performance-avoidance goals, one common feature and limitation of these various contributions is to consider first-generation students as a homogenous group. Instead, it is important to stress out that first-generation students differ on several dimensions, one of these dimensions - particularly central in university contexts - is the level of academic achievement. Specifically, a high level of academic achievement at university is a sign of academic success. Consequently, for first-generation students, a high level of academic achievement might indicate that the upward mobility process is close to being achieved. In support of this idea, research has shown that achievement is involved in the identity management process. Ellemers, Van Knippenberg, de Vries, and Wilke (1988) manipulated participants' group status and demonstrated that when facing upward mobility opportunities, low status group members with a high level of achievement on a given task are the most engaged in this process compared with low status member with a low level of achievement. In the same vein, Boen and Vanbeselaere $(2001,2002)$ followed a similar procedure and found that low status high achieving people prefer individual strategies, such as individual mobility, compared with low achievers.

Thus, the higher the first-generation students' academic achievement level, the more likely they are to experience the upward mobility process as well as the identity threatening processes associated with it. Because identity change and identity threat processes are, in turn, associated with avoidance strategies, including performance-avoidance goals, first-generation students with a high level of academic achievement are particularly likely to endorse performance-avoidance goals. Conversely, firstgeneration students with a low level of academic achievement are not in the way of success; therefore, they do not have to face an identity change (Ellemers et al., 1988; see also Boen \& Vanbeselaere, 2001, 2002). Consequently, they have few reasons to feel threatened by this situation and in turn adopt performance-avoidance goals. 


\section{Overview}

The present research tested whether social class and academic achievement interact to predict performance-avoidance goal endorsement. The higher the academic achievement, the more firstgeneration students should experience an upward mobility process and thus the more they should be prone to endorse performance-avoidance goals. This hypothesis will be tested in three studies, with the measure of performance-avoidance goals linked to one's studies in general (Study 1), one's class (Studies 2 and 3), and one's exam (Study 3), using different indicators of academic achievement (high school exit exam grade in Study 1; fall semester grades in Studies 2 and 3).

\section{Study 1}

Method

\section{Participants}

Two hundred thirty-four first-year psychology students enrolled in a psychology course in a French university participated in the study. Eighteen participants were excluded due to missing data (11 did not report their grades and 7 did not report their parents' level of education). The final sample included 216 participants (31 men and 185 women), with a mean age of 18.93 years $(S D=1.73)$.

\section{Material and procedure}

Participants completed the questionnaire during a large methodology lecture that took place at the beginning of the fall semester.

Achievement goals. The three-item performance-avoidance scale was extracted from Elliot and McGregor's (2001) Achievement Goal Questionnaire (validated in French by Darnon \& Butera, 2005). Instructions for the questionnaire stated: "Questions that follow refer to your studies in general. Please indicate to what extent each statement is true for you in your studies." Participants indicated their degree of agreement on a 7-point scale, ranging from 1 "Not at all true of me" to 7 "Very true of me" (e.g., "I just want to avoid doing poorly in my studies"). Responses were averaged to form the performanceavoidance goals score $(\alpha=.50, M=5.17, S D=1.23)$. To make sure the effects would be specific to performance-avoidance goals and would not apply to any type of achievement goal, participants also completed the three-item mastery-approach goal scale $(\alpha=.84, M=5.47, S D=1.18)$ and the three-item performance-approach goal scale $(\alpha=.86, M=3.67, S D=1.64)$ extracted from the same questionnaire.

Generational status. Participants reported their mothers and fathers' highest degrees. The baccalauréat (i.e., the French high school exit exam) was used as the criterion because it determines whether one will get access to higher education. Participants for whose neither parent had passed the baccalauréat were coded as first-generation students. If at least one of the students' parents had earned a degree (the baccalauréat or a higher degree), student was classified as a continuing-generation student (for a comparable procedure, see Harackiewicz et al., 2014; Stephens et al., 2012a, 2012b, 2012c; Stephens, Hamedani, \& Destin, 2014). Based on this classification, 94 students were coded as firstgeneration students and 122 as continuing-generation students.

Level of academic achievement. As participants were at the beginning of their studies, we asked them to report their grade on the high school exit exam (baccalauréat), which could range from 10 (passing level) to $20(M=11.68, S D=1.38$, ranging from 10 to 16.9$)$. Intercorrelations among variables are presented in Table 1. It is worth noting that generational status did not significantly predict academic achievement, $B=0.10, F(1,214)=1.06, p=.30$. 
Table 1

Zero-order correlations among variables (Study 1).

\begin{tabular}{lcc}
\hline Variables & 1 & 2 \\
\hline 1. Level of academic achievement & & \\
2. Performance-avoidance goals in one's studies & -.01 & $-.17^{*}$ \\
3. Generational status & .07 & \\
\hline Note. Generational status was scored -1 for first-generation students and +1 for \\
continuing-generation students. \\
$* p<.05$.
\end{tabular}

Results

We expected generational status to interact with academic achievement on performance-avoidance goal endorsement. Indeed, first-generation students with higher academic achievement should be more likely to endorse performance-avoidance goals as compared with continuing-generation students. Regression analyses were conducted to test this hypothesis. The model integrated three predictors: generational status (coded -1 , first-generation, +1 , continuing-generation), academic achievement (centered), and the interaction between these two variables. Since several previous studies have suggested that gender predicted performance-avoidance goals (Elliot \& Church, 1997; Howell \& Buro, 2009; Smith, 2004), and since gender conveys social status (Fiske, 2010), this variable was included in preliminary analyses. The main effect of gender was significant in Study $1, B=-0.49, F(1,211)=18.02, p<.001, \eta \mathrm{p}^{2}=.08$, and in other studies (Study 2: $B=-0.37, F(1,252)=9.69, p=.002, \eta \mathrm{p}^{2}=.04$; Study 3: $B=-0.67$, $F(1,281)=40.35, p<.001, \eta \mathrm{p}^{2}=.13$, for performance-avoidance goals in the class and, $B=-0.48$, $F(1,281)=23.32, p<.001, \eta \mathrm{p}^{2}=.08$, for performance-avoidance goals in the exam). Women reported higher level of performance-avoidance goals compared with men. Thus, gender was entered in all subsequent analyses as a covariate. As gender never interacted with other variables, interactions involving gender were not retained in the final model.

Means are presented in Table 2. The main effect of status indicated that first-generation students $(M=$ $5.43, S D=1.03$ ) reported a higher level of performance-avoidance goals compared with continuinggeneration students $(M=4.99, S D=1.35), B=-0.19, F(1,211)=5.49, p=.020, \eta p^{2}=.03$. Academic achievement was not related to performance-avoidance goals adoption, $B=0.04, F(1,211)<1$. However, as expected, the interaction between status and level of academic achievement was significant, $B=-0.15, F(1,211)=6.00, p=.015, \eta \mathrm{p}^{2}=.03$. As shown in Fig. 1, no difference occurred between first-generation and continuing-generation students with a low level of academic achievement (1 SD below the mean), $B=0.01, F(1,211)<1$; the difference appeared only among high achievers $(1 S D$ above the mean), $B=-0.39, F(1,211)=11.32, p=.001, \eta p^{2}=.05$. It should be noted that in this study, like in the two others, $\eta \mathrm{p}^{2}$ ranged between .01 and .05 . These effect sizes can be qualified as small, implying that interpretations of the results and linked conclusions must be done with caution. 


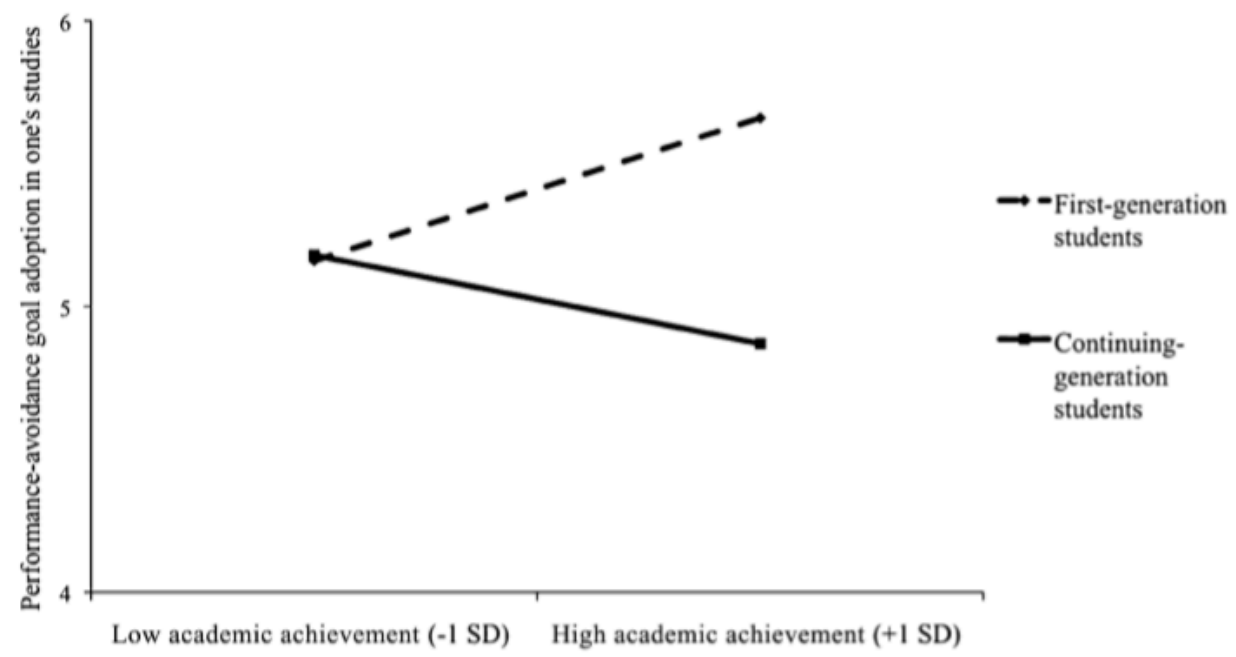

Fig. 1. Performance-avoidance goal adoption as a function of the level of academic achievement and generational status (Study 1).

The same analyses were repeated with mastery-approach and performance-approach goals. The results revealed no main or interaction effects for these variables (all $F_{S}<2, n s$ ).

Moreover, because of the low Cronbach's alphas, in additional analyses, we conducted factorial analyses that included nine items (performance-avoidance, performance-approach, and mastery-approach). Then, the factorial score on the performance-avoidance goal factor was regressed on the model. The results confirmed the main effect of status, $B=-0.14, F(1,208)=4.24, p=.041, \eta \mathrm{p}^{2}=.02$ and the interaction between status and achievement, $B=-0.12, F(1,208)=6.57, p=.011, \eta p^{2}=.03$. As in previous analyses, the effect of academic achievement was not significant, $B=0.01, F(1,208)<1$.

Table 2

Mean performance-avoidance goal adoption (with standard deviations) in the three studies.

\begin{tabular}{|c|c|c|c|c|}
\hline & \multicolumn{2}{|c|}{ First-generation } & \multicolumn{2}{|c|}{ Continuing-generation } \\
\hline & $n$ & $M(\mathrm{SD})$ & $n$ & $M(\mathrm{SD})$ \\
\hline Study 1 & 94 & $5.43(1.03)$ & 122 & $4.99(1.33)$ \\
\hline Study 2 & 104 & $4.31(1.47)$ & 153 & $3.88(1.50)$ \\
\hline \multicolumn{5}{|l|}{ Study 3} \\
\hline In the class & 124 & $4.15(1.40)$ & 162 & $3.82(1.33)$ \\
\hline On the exam & & $4.47(1.28)$ & & $3.99(1.24)$ \\
\hline
\end{tabular}

\section{Discussion}

The present study supports the hypothesis that at university, first-generation psychology students adopt more performance-avoidance goals compared with continuing-generation students. This result supports that beyond individual characteristics identified in the goal literature, social class should be considered as another element that is potentially associated with performance-avoidance goal adoption. More importantly, the expected interaction effect between status and level of academic achievement on performance-avoidance goal endorsement revealed that the higher the level of academic achievement, the higher the difference between first-generation and continuing-generation students. In other words, despite their high academic achievement, which should prevent them from adopting performanceavoidance goals (Elliot \& McGregor, 2001; Elliot \& Reis, 2003; Pulfrey et al., 2011; Senko \& Harackiewicz, 2005), first-generation students with a high level of academic achievement endorse more performance-avoidance goals compared with their continuing-generation counterparts. This finding 
supports the idea that the adoption of performance-avoidance goals can be another component of the difficulties experienced by those engaged in an upward mobility process. It is worth noting that as expected, such effects emerged only for performance-avoidance goals but not for other types of goals, which supports our interpretation in terms of avoidant, maladaptive strategies that first-generation students experience when they succeed at university.

The first study is the first step toward showing the link among social class, academic achievement, and performance-avoidance goals. However, the first study measured general performance-avoidance goals regarding one's studies. Some authors (Ames, 1992; Turner et al., 2002) suggested that the classroom environment plays a crucial role in the adoption of achievement strategies, specifically avoidance ones. As goals are influenced by the classroom context, they might vary across different classes. Huang (2012) and Baranik, Barron, and Finney (2010) proposed using specific formulations rather than general formulations to change constructs like achievement goals. Therefore, replicating the effects obtained in Study 1 with a context specific measure of performance-avoidance goals (e.g., in one's class) appears to be a relevant follow-up of the present findings.

Moreover, in Study 1, baccalauréat score was used as a proxy for level of academic achievement. Although baccalauréat scores are often related to university success, what is required for the baccalauréat exam is quite different from what is required in university classes. One could then wonder whether baccalauréat score is a good proxy for academic achievement at the university level. In Study 2 , the level of academic achievement was determined through the grade students obtained during the fall semester in a very similar class. Finally, to prevent distortion in self-reported grades (Chatard, Guimond, \& Selimbegovic, 2007; Kuncel, Credé, \& Thomas, 2005), this grade was obtained directly from the Psychology department.

\section{Study 2}

Method

Participants

Two hundred seventy-three first-year French psychology students enrolled in social psychology workshops participated in the study. Missing data resulted in 16 participants being eliminated from the analyses (6 students did not answer to the status measure, 1 student did not respond to the performanceavoidance goals scale, and 9 students did not take the fall semester test). The final sample included 257 participants (44 males, 213 females), with a mean age of 19.35 years $(S D=1.67)$.

\section{Material and procedure}

Students answered the questionnaire at the beginning of their second social psychology workshop during the spring semester. These workshops were identical for every student and taught by eight different teachers. It should be noted that even if eight groups is quite a small sample size for multilevel analysis (Maas \& Hox, 2004), Intraclass correlation (ICC) coefficient was calculated for the performanceavoidance goals. As this ICC was not significant (ICC $=.02$, Wald $Z=.71, n s$ ), multi-level analyses were not conducted.

Achievement goals. The same three-item measure of performance-avoidance $(\alpha=.76, M=4.06$, $S D=1.50)$, performance-approach $(\alpha=.92, M=3.60, S D=1.53)$, and mastery-approach goals $(\alpha=.90$, $M=5.81, S D=1.09$ ) were used as in Study 1 . However, students were specifically asked to report their level of goal "in the social psychology workshop".

Generational status. Study 1's indicator was used, resulting in 104 participants being coded as first-generation and 153 as continuing-generation students. 
Level of academic achievement. Fall semester social psychology workshop grades, which could range from 0 (the worst) to 20 (the best) $(M=12.12, S D=4.19$, ranging between 0.17 and 19.17), were obtained from the psychology office. This fall semester workshop was very similar to the spring semester workshop in its form, only the content differed. Intercorrelations among variables are presented in Table 3. It is worth noting that generational status was marginally related to academic achievement, $B=0.50, F(1,255)=3.74, p=.054$.

\section{Results}

As in Study 1, we expected status to interact with academic achievement on performance-avoidance goal endorsement. Therefore, the same regression model as in Study 1 was used. The effect of status on performance-avoidance goal adoption was marginal, $B=-0.17, F(1,252)=3.58, p=.06, \eta \mathrm{p}^{2}=.01$. First-generation students $(M=4.31, S D=1.47)$ tended to report a higher adoption of performanceavoidance goals compared with continuing-generation students $(M=3.88, S D=1.50)$. Moreover, academic achievement was negatively associated with performance-avoidance goals, $B=-0.06$, $F(1,252)=8.43, p=.004, \eta \mathrm{p}^{2}=.03$. More importantly, the hypothesized interaction between status and level of academic achievement was significant, $B=-0.05, F(1,252)=4.87, p=.028, \eta \mathrm{p}^{2}=.02$. As can be seen in Fig. 2, no difference emerged between first-generation and continuing-generation students with a low level of academic achievement, $B=0.03, F(1,252)<1$. For high achievers, however, firstgeneration students endorsed more performance-avoidance goals compared with continuing-generation students, $B=-0.38, F(1,252)=8.14, p=.005, \eta \mathrm{p}^{2}=.03$.

The same analyses were repeated with mastery-approach and performance-approach goals. The results revealed only a positive main effect of academic achievement on mastery-approach, $B=0.07, F(1,252)$ $=16.02, p<.001, \eta \mathrm{p}^{2}=.06$ and performance-approach goals, $B=0.05, F(1,252)=5.14, p=.024, \eta \mathrm{p}^{2}$ $=.02$. All other main or interaction effects were non-significant, all $F_{S}<2, n s$.

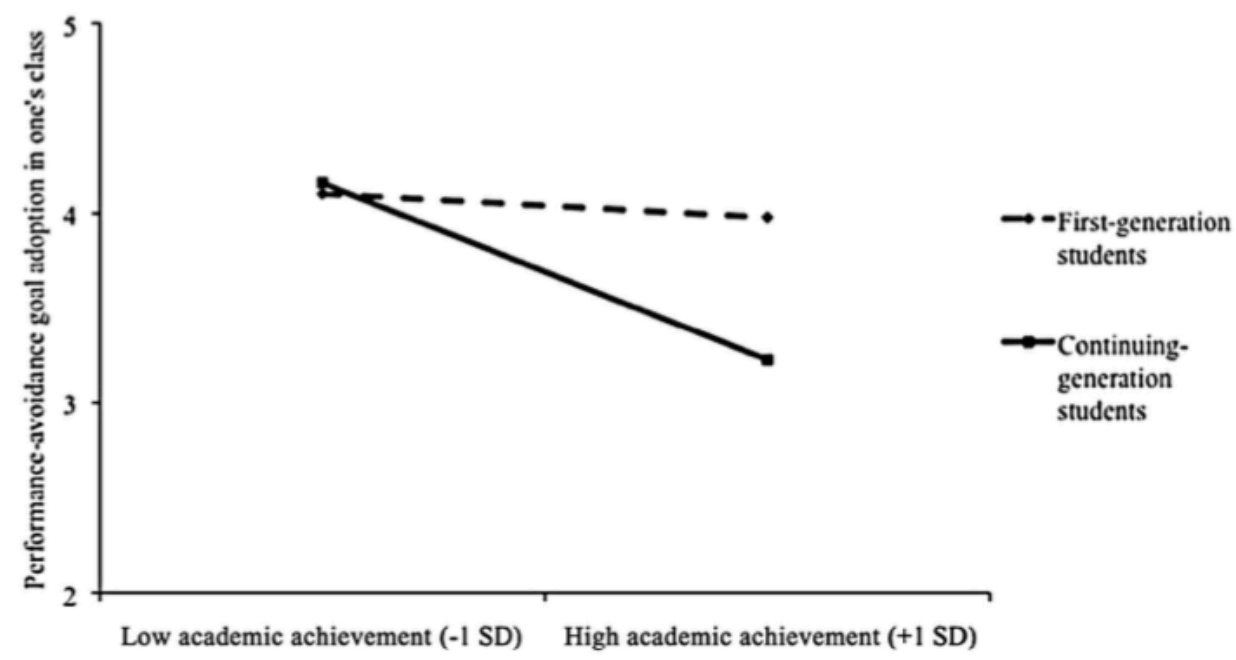

Fig. 2. Performance-avoidance goal adoption as a function of the level of academic achievement and generational status (Study 2).

It is worth noting that as in Study 1, additional factorial analyses included nine items measuring performance-avoidance, performance-approach, and mastery-approach. Regressing the factorial score of performance-avoidance goals on the model confirmed the main effect of status, $B=-0.13, F(1,248)$ $=4.17, p=.042, \eta \mathrm{p}^{2}=.02$ and the interaction between status and achievement, $B=-0.03, F(1,248)=$ 4.93, $p=.027, \eta \mathrm{p}^{2}=.02$. Academic achievement was a negative predictor of performance-avoidance factorial scores, $B=-0.04, F(1,248)=8.52, p=.004, \eta p^{2}=.03$. 


\section{Discussion}

Study 2 was designed to replicate Study 1's results with a class-specific measure of performanceavoidance goals and with a more appropriate measure of academic achievement. The data indicated that - controlling for the level of academic achievement - first-generation students tended to adopt more performance-avoidance goals compared with continuing-generation students. More importantly, the interaction confirmed that first-generation and continuing-generation students differ only when they are high achievers. Thus, the two studies confirmed that beyond actual academic achievement, students' socio class might also contribute to orienting psychology's students toward performance-avoidance goals. Although first-generation students with high academic achievement have no reasons to doubt their chances of success or adopt performance-avoidance goals, the upward mobility process they are experiencing may favor avoidance of goal endorsement.

It is worth noting that the above interaction emerged for both a general measure of academic achievement (i.e., baccalauréat grade, Study 1) and a measure specific to the psychology classes (Study 2). Study 2 , however, was carried out just after students' exam and before official grades were delivered, that is, before students were informed of their grades for the preceding semester class. This implies that, at the time the study was conducted, students did not know their true level of academic achievement (e.g., a high achievers did not know whether they performed well on the exam). This situation might have resulted in students having a certain degree of uncertainty regarding their achievement. Uncertainty can increase in-group identification (Grieve \& Hogg, 1999) and students' reliance on the group to which they belong when estimating their level of academic achievement. Would status continue to predict high achievers' level of performance-avoidance goals after students receive explicit and non-ambiguous feedback about their actual achievement? This question was addressed in Study 3, which was conducted 2 months after students received their grade for their fall semester's social psychology exam. In addition, Study 3 included an exam-oriented measure of performance-avoidance goals, a measure that is close in its form to the recent conceptualization of performance-avoidance goals (Elliot et al., 2011). Generational status and academic achievement are expected to interact with both performanceavoidance goals in the class and performance-avoidance goals in the exam.

\section{Study 3}

Method

\section{Participants}

Two hundred ninety-two first-year psychology students enrolled in a psychology course at a French university participated in the third study. Six participants were excluded due to missing data (they did not participate to the fall semester exam), resulting in a sample of 286 students (43 males, 243 females), with a mean age of 19.40 years $(S D=1.58)$.

\section{Material and procedure}

As in Study 2, Study 3 was conducted in social psychology workshops during the spring semester. Five different teachers taught this workshop. As in Study 2, the ICC was not significant (ICC $=.02$, Wald $Z$ $=.71, n s$ ), confirming that performance-avoidance goals residuals were independent from the teacher level and that multi-level analyses did not have to be conducted.

Students answered the questionnaire at the beginning of the last workshop of the semester. At that time, they received their fall semester grade (about 2 months earlier), and they were preparing for the spring semester exam (three weeks later).

Achievement goals. The same three items of performance-avoidance goals, mastery-approach goals, and performance-approach goals were used as in Study 2. Instructions were the same as in Study 
2 and referred to participants' social psychology class $(\alpha=.64, M=3.96, S D=1.37$ for performanceavoidance goals, $\alpha=.85, M=5.42, S D=1.19$ for mastery-approach goals and $\alpha=.90, M=3.26, S D=$ 1.56 for performance-approach goals). In addition, three other items referring to performance-avoidance goals in their social psychology exam were included. More precisely, students were asked to think about the social psychology exam rather than about their social psychology class and to report their performance-avoidance goals in this exam (e.g., "My fear of performing poorly on my social psychology exam is often what motivates me"). Participants answered on a 7-point scale $(\alpha=.54, M=4.20, S D=$ 1.28).

Generational status. The same indicator as in the two first studies was used, resulting in 124 participants being coded as first-generation and 162 as continuing-generation students.

Level of academic achievement. As in Study 2, fall semester social psychology workshop grades were obtained from the psychology office $(M=11.34, S D=3.70$, ranging from 2.20 to 20$)$. Intercorrelations among variables are presented in Table 4. Status was not significantly related to academic achievement, $B=0.00, F(1,284)<1$.

Table 4

Zero-order correlations among variables (Study 3).

\begin{tabular}{llll}
\hline Variables & 1 & 2 & 3 \\
\hline 1. Level of academic achievement & & & \\
2. Performance-avoidance goals in one's class & .02 & & \\
3. Performance-avoidance goals in one's exam & .03 & $.82^{* *}$ & \\
4. Generational status & .001 & $-.12^{*}$ & $-.19^{* *}$ \\
\hline Note. Generational status was scored -1 for first-generation students and +1 for \\
continuing-generation students. \\
${ }^{*} p<.05 ;{ }^{* *} p<.01$.
\end{tabular}

Results

As in Studies 1 and 2, Study 3 tested whether generational status interacted with academic achievement to predict performance-avoidance goal endorsement. As in the two previous studies, at a high level of academic achievement, first-generation students were expected to endorse more performance-avoidance goals in their social psychology class and in their social psychology exam compared with continuinggeneration students.

\section{Performance-avoidance goals in the social psychology class}

The same regression model as in Studies 1 and 2 was tested. A marginal effect of status, $B=-0.13$, $F(1,281)=3.05, p=.082, \eta \mathrm{p}^{2}=.01$, indicated that first-generation students $(M=4.15, S D=1.40)$ tended to endorse more performance-avoidance goals compared with continuing-generation students $(M$ $=3.82, S D=1.33)$. Level of academic achievement was not significantly associated with performanceavoidance goal adoption, $B=0.01, F(1,281)<1$. However, the interaction between status and level of academic achievement was significant, $B=-0.04, F(1,281)=4.13, p=.043, \eta \mathrm{p}^{2}=.01$. As shown in Fig. 3, at a low level of academic achievement, the difference in performance-avoidance goal adoption between first-generation and continuing-generation students was not significant, $B=0.02, F(1,281)<$ 1. At a high level of academic achievement, first-generation students reported more performanceavoidance goals compared with continuing-generation students, $B=-0.29, F(1,281)=7.00, p=.009$, $\eta \mathrm{p}^{2}=.02$. 
Once again, the same analyses were repeated for mastery-approach and performance-approach goals. The results revealed only a positive main effect of level of academic achievement on mastery-approach, $B=0.12, F(1,281)=46.41, p<.001, \eta \mathrm{p}^{2}=.14$, and performance-approach goals, $B=0.12, F(1,281)=$ 23.41, $p<.001, \eta \mathrm{p}^{2}=.07$. No other main or interaction effects reached significance, all $F_{S}<3, n s$.

\section{Performance-avoidance goals on the social psychology exam.}

The main effect of status was significant, $B=-0.22, F(1,281)=9.15, p=.003, \eta \mathrm{p}^{2}=.03$, with firstgeneration students $(M=4.47, S D=1.28)$ reporting more performance-avoidance goals for the exam compared with continuing-generation students $(M=3.99, S D=1.24)$. Academic achievement was not significantly related to performance-avoidance goal adoption in the exam, $B=0.01, F(1,281)<1$. However, the interaction between status and level of academic achievement was significant, $B=-0.05$, $F(1,281)=6.04, p=.015, \eta \mathrm{p}^{2}=.02$. As shown in Fig. 3, the same pattern was obtained for the exam as for the class. For students with a low level of academic achievement, performance-avoidance goals did not depend on status, $B=-0.04, F(1,281)<1$, whereas among students with a high level of academic achievement, first-generation students adopted more performance-avoidance goals compared with continuing-generation students, $B=-0.39, F(1,281)=14.76, p<.001, \eta p^{2}=.05$. As in studies 1 and 2 , since the Cronbach's alphas for performance-avoidance goals were quite low, additional factorial analyses were conducted that included 12 items (performance-avoidance, performance-approach, mastery-approach, performance-avoidance goals in the exam). Since performance-avoidance in the class and in the exam loaded on the same factor, only one performance-avoidance goals score was computed. Regressing this score on the model confirmed the significant main effect of status, $B=-0.14, F(1,278)$ $=6.13, p=.014, \eta \mathrm{p}^{2}=.02$ and the significant interaction between status and achievement, $B=-0.03$, $F(1,278)=5.11, p=.025, \eta \mathrm{p}^{2}=.02$. There was no effect of academic achievement, $B=-0.01, F(1,278)$ $<1$.
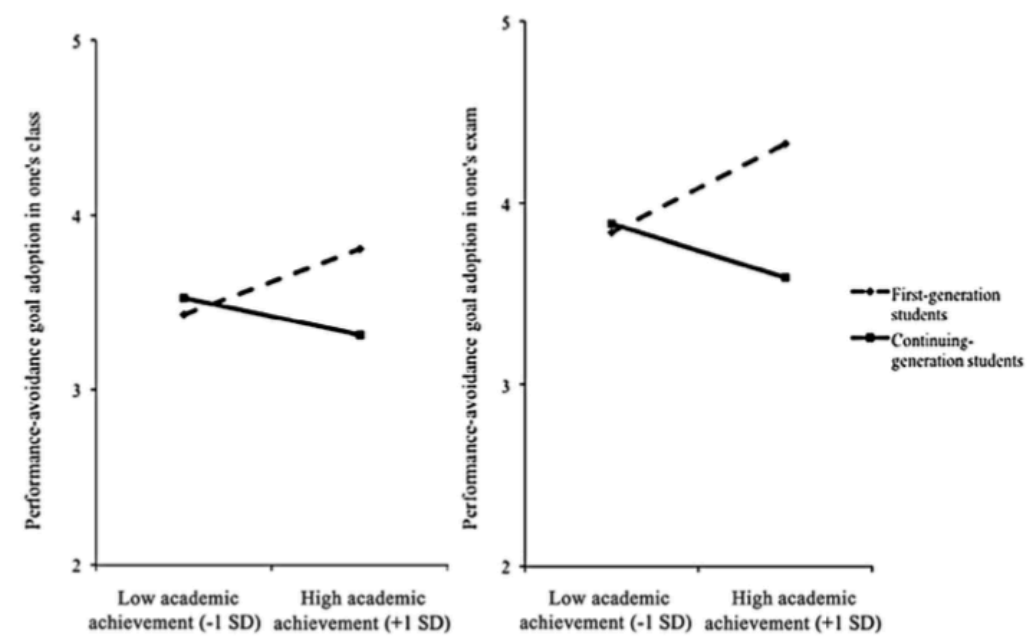

Fig. 3. Performance-avoidance goal adoption in the class (left side) and on the exam (right side) as a function of academic achievement and generational status (Study 3).

\section{Discussion}

The aim of this last study was to test whether the interaction between the level of academic achievement and status would be maintained after students had received their grade, that is, once they were aware of their level of academic achievement. The data confirmed that first-generation students tended to endorse performance-avoidance goals more than did continuing-generation students. Nevertheless, and as previously observed, the interaction between the level of academic achievement and status drives this main effect. The higher the academic achievement, the more first-generation and continuing-generation students diverge in term of performance-avoidance goal endorsement. Interestingly, this last study also 
showed the same pattern for exam-oriented performance-avoidance goals (see Elliot et al., 2011, for a similar framing of the goal items), which increases the generalizability of this finding.

\section{General discussion}

What leads psychology students to adopt performance-avoidance goals? As previously discussed, the existing research has established that numerous antecedents of performance-avoidance goals exist, including fear of failure, negative emotions, or academic achievement (Elliot \& McGregor, 2001; Elliot \& Reis, 2003; Pulfrey et al., 2011; Senko \& Harackiewicz, 2005). All these previously examined constructs are individual, person-focused antecedents. In the present paper, we argued that beyond these individual characteristics, social position within a system (i.e., social class) also predicts performanceavoidance goal endorsement. Moreover, we argued that the level of academic achievement should moderate this effect. Indeed, first-generation students with a high level of academic achievement should experience an upward mobility process most fiercely, and consequently, endorse performanceavoidance goals the most.

The three studies presented herein supported our hypotheses; indeed, the results showed that firstgeneration students tended to report a higher level of performance-avoidance goals compared with continuing-generation students. More importantly, the interaction between the level of academic achievement and generational status consistently drove this difference. As expected, at a low level of academic achievement, first-generation and continuing-generation students did not differ in their performance-avoidance goal adoption, but at a high level, first-generation students reported a higher level of performance-avoidance goal adoption compared with continuing-generation students. These results were obtained using a measure assessing students' goals regarding their studies in general (Study 1), their classroom goals (Studies 2 and 3), and their exam goals (Study 3). Moreover, these findings were obtained before students knew their actual grade (Studies 1 and 2) and were replicated after students received their academic grade (Study 3), namely, in a situation in which students had objective information regarding their level of academic achievement. Finally, the effects emerged for a general measure of their achievement (Study 1) as well as a domain-specific one (Studies 2 and 3). As expected, these effects were specific to performance-avoidance goals. Indeed, they did not appear for other types of goals, which tended to support our interpretation in terms of avoidant and maladaptive motivation, which high achievers of first-generation endorse when experiencing mobility.

Several authors have suggested testing whether social class is linked to goal endorsement (Darnon et al., 2012; Elliot, 1999; Huang, 2012), but thus far, empirical research has never addressed this hypothesis directly. Our research is the first to provide empirical evidence that beyond individual characteristics, social class can be considered a predictor of performance-avoidance goal endorsement. Moreover, our findings indicated that this seems to be true only for high achievers. Indeed, for high achieving firstgeneration students, entering a university is the beginning of an individual upward mobility process, and achieving this process can be difficult as well as threaten their identity (Jetten et al., 2008; Johnson et al., 2011; Lee \& Kramer, 2013; Ostrove \& Long, 2007; Reay et al., 2009). More specifically, because of high achievers' academic success, they are closer to the mobility process compared with low achievers and therefore experience the threat associated with identity change the most (Jetten et al., 2008).

This identity management process can be particularly difficult, notably because people who pursue individual mobility face the risk of encountering double discrimination: from the old group to which they belonged and from members of the new group they try to enter (Branscombe \& Ellemers, 1998; Branscombe, Wann, Noel, \& Coleman, 1993; Warner, Hornsey, \& Jetten, 2007). Moreover, the ingroup and/ or outgroup does not always support individual upward mobility (Van Laar, Bleeker, Ellemers, \& Meijer, 2014). A possible response to this threatening state can be the adoption of performanceavoidance goals (Brodish \& Devine, 2009; Chalabaev et al., 2008; Ryan \& Ryan, 2005; Smith, 2004; Ståhl, Van Laar, \& Ellemers, 2012). 
Some limitations of these findings should be noted. First, the variables were all invoked variables. Thus, our studies do not allow us to make conclusions about causal relationships among social class, academic achievement, and performance-avoidance goal endorsement. The present results were consistently obtained across the three studies (Cohen, 1994). Nonetheless, since in the goal literature, academic achievement is considered both an antecedent (Elliot \& McGregor, 2001; Pulfrey et al., 2011; Senko \& Harackiewicz, 2005) and a consequence of performance-avoidance goal endorsement (Elliot \& Church, 1997; Van Yperen et al., 2014), future research should replicate the present findings while manipulating participants' group status and achievement. As an example, Ellemers and colleagues (1988, see also Scheepers \& Ellemers, 2005) manipulated participants' group status through a group-level feedback and

participants' achievement through an individual feedback. In this experiment, Ellemers et al. (1988) found that when mobility is possible, participants who were put on a low status-high achieving position identified less with their ingroup compared with those who were put on a low status low achieving position. We think they should also be more prone to endorse performance-avoidance goal. Second, our performance-avoidance goal measure is not optimal. First, even if this scale was used successfully in the past, Cronbach's alphas ranged from poor (.50) to acceptable (.76) across the three studies. Furthermore, recent conceptualizations of performance goals make the reference to social comparison in the measurement of performance-avoidance goals more explicit (Elliot et al., 2011). Although the measure we used in the present research is still frequently being used in current goal research (e.g., Putwain, Larkin, \& Sander, 2013; Sommet et al., 2014), replicating the present studies with a more recent measure of performance-avoidance goals would allow an examination of whether the inclusion of social comparisons in the measure of performance-avoidance goals changes the findings. Furthermore, it cannot be concluded whether the difference between first-generation and continuinggeneration students in performance-avoidance goal adoption reflects a measurement bias. Indeed, since first-generation and continuing-generation students differ in terms of cultural values (Stephens et al., 2012a, 2012b), the measurement of performance-avoidance goals may not be equivalent within the two status groups. As suggested by Zusho and Clayton (2011), examining invariance of the achievement goal questionnaire across cultural groups (such as social status) would clarify this issue.

It is also important to note that the results are interpreted through the identity management process, which first-generation students with a high level of academic achievement may face in the context of upward mobility. In line with previous research (Jetten et al., 2008; Stephens et al., 2012a, 2012b), we think that the poor experience of fit might explain why first-generation students who perform well endorse performance-avoidance goals. However, future research should identify whether the processes associated with upward mobility (e.g., the sense of academic fit, Walton \& Cohen, 2007) mediate the findings.

Finally, the three studies were conducted with psychology students. Most studies on which the present research is based examined psychology students (e.g., Brodish \& Devine, 2009; Croizet \& Claire, 1998; Darnon et al., 2009b; Elliot \& Church, 1997; Elliot \& McGregor, 2001; Iyer et al., 2009; Murayama \& Elliot, 2012; Van Yperen, 2006; Zusho et al., 2005). However, replicating the results in other academic domains (e.g., business, medical, law, arts) would increase the external validity of the findings.

Interestingly, even if gender was included in the analyses only as a control variable, the three studies showed a consistent main effect of gender, with women reporting a higher level of performanceavoidance goals compared with men, confirming the results obtained previously (Elliot \& Church, 1997; Howell \& Buro, 2009; Smith, 2004). Gender is a relevant indicator of status in our society, as men occupy better social positions, earn more money, and are judged to be more competent compared with women (Fiske, 2010). Thus, the fact that women endorse more performance-avoidance goals compared with men supports the idea that a social position can affect performance-avoidance goal endorsement. The very unequal distribution of participants in terms of gender makes it hard to draw a clear conclusion on this point; however, future research should examine whether gender is an antecedent of performanceavoidance goal endorsement. 
As mentioned earlier, the effects sizes reported in the three studies oscillate from small to moderate. Therefore, caution is required regarding the practical implications of the present findings. In particular, more research is needed to test additional factors that predict performance-avoidance goals endorsement and that may more strongly contribute to educational inequities. However, we think the present results point to an important issue that deserves attention. Indeed, several authors have argued that in a university as well as other contexts, people are inclined to see inequalities as justified (Jost et al., 2004; Jost, Kay, \& Thorisdottir, 2009). The present studies suggest that inequalities that are fundamentally social (social-class inequalities) can be internalized by first-generation and continuing-generation students in the form of differential achievement goal adoption, at least in some contexts like psychological studies. In other words, one might be tempted to explain lower success of first-generation students by the fact that they are pursuing the "wrong goals" at university, an interpretation that can be particularly useful for justifying the very underachievement of these students (Jost \& Hunyady, 2005; Van Laar \& Sidanius, 2001). However, such interpretation conceals the fact that this goal endorsement stems from one's social-class background. In practice, we do believe that educators should be aware of the potential risk of interpreting social-class differences in terms of motivational differences and keep in mind that what might initially appear to be an individual characteristic (e.g., a high level of performance-avoidance goal endorsement) can actually be, at least partially, a consequence of social belongings (e.g., being a member of low status groups).

\section{Acknowledgments}

This research was supported by the French Agence Nationale de la Recherche (ANR 11 INEG 002 02), the Swiss National Science Foundation (SINERGIA), and the Région Auvergne.

\section{References}

Ames, C. (1992). Classrooms: goals, structures, and student motivation. Journal of Educational Psychology, 84(3), 261-271. doi:10.1037/0022-0663.84.3.261.

Amiot, C. E., Terry, D. J., Wirawan, D., \& Grice, T. A. (2010). Changes in social identities over time: the role of coping and adaptation processes. British Journal of Social Psychology, 49(4), 804-826. doi:10.1348/014466609X480624.

Baranik, L. E., Barron, K. E., \& Finney, S. J. (2010). Examining specific versus general measures of achievement goals. Human Performance, 23(2), 155-172. doi:10.1080/08959281003622180.

Bipp, T., Steinmayr, R., \& Spinath, B. (2008). Personality and achievement motivation: relationship among Big Five domain and facet scales, achievement goals, and intelligence. Personality and Individual Differences, 44(7), 1454-1464. doi:10.1016/ j.paid.2008.01.001.

Boen, F., \& Vanbeselaere, N. (2001). Individual versus collective responses to membership in a low-status group: the effects of stability and individual ability. The Journal of Social Psychology, 141(6), 765-783. doi:10.1080/ 00224540109600587.

Boen, F., \& Vanbeselaere, N. (2002). The relative impact of socio-structural characteristics on behavioral reactions against membership in a low-status group. Group Processes \& Intergroup Relations, 5(4), $299-318$. doi:10.1177/ 1368430202005004003.

Bourdieu, P., Passeron, J. C., \& Nice, J. P. (1990). Reproduction in education, society and culture. London: Sage. Branscombe, N. R., \& Ellemers, N. (1998). Coping with group-based discrimination: individualistic versus grouplevel strategies. In J. K. Swim \& C. Stangor (Eds.), Prejudice: The target's perspective (pp. 243-266). New York: Academic Press. 
Branscombe, N. R., Wann, D. L., Noel, J. G., \& Coleman, J. (1993). In-group or out-group extremity: importance of the threatened social identity. Personality and Social Psychology Bulletin, 19(4), 381-388. doi:10.1177/0146167293194003.

Brodish, A. B., \& Devine, P. G. (2009). The role of performance-avoidance goals and worry in mediating the relationship between stereotype threat and performance. Journal of Experimental Social Psychology, 45(1), 180-185. doi:10.1016/ j.jesp.2008.08.005.

Brophy, J. (2005). Goal theorists should move on from performance goals. Educational Psychologist, 40(3), 167176. doi:10.1207/s15326985ep4003_3.

Chalabaev, A., Sarrazin, P., Stone, J., \& Cury, F. (2008). Do achievement goals mediate stereotype threat? An investigation on females' soccer performance. Journal of Sport \& Exercise Psychology, 30(2), 143-158.

Chatard, A., Guimond, S., \& Selimbegovic, L. (2007). "How good are you in math?" The effect of gender stereotypes on students' recollection of their school marks. Journal of Experimental Social Psychology, 43(6), 1017-1024. doi:10.1016/ j.jesp.2006.10.024.

Cohen, J. (1994). The earth is round ( $<$.05). American Psychologist, 49(12), 997-1003. doi:10.1037/0003066X.49.12.997.

Croizet, J. C., \& Claire, T. (1998). Extending the concept of stereotype and threat to social class: the intellectual underperformance of students from low socioeconomic backgrounds. Personality and Social Psychology Bulletin, 24(6), 588-594. doi:10.1177/0146167298246003.

Croizet, J. C., Désert, M., Dutrévis, M., \& Leyens, J.-P. (2001). Stereotype threat, social class, gender, and academic under-achievement: when our reputation catches up to us and takes over. Social Psychology of Education, 4(3-4), 295-310. doi:10.1023/A:1011336821053.

Cury, F., Da Fonséca, D., Rufo, M., \& Sarrazin, P. (2002). Perceptions of competence, implicit theory of ability, perception of motivational climate, and achievement goals: a test of trichotomous conceptualization of endorsement of achievement motivational in the physical education setting. Perceptual and Motor Skills, 95(1), 233-244. doi:10.2466/PMS.95.4.233-244.

Cury, F., Elliot, A. J., Da Fonseca, D., \& Moller, A. C. (2006). The social-cognitive model of achievement motivation and the $2 \times 2$ achievement goal framework. Journal of Personality and Social Psychology, 90(4), 666-679. doi:10.1037/0022-3514.90.4.666.

Darmon, N., \& Drewnowski, A. (2008). Does social class predict diet quality? The American Journal of Clinical Nutrition, 87(5), 1107-1117.

Darnon, C., \& Butera, F. (2005). Buts d'accomplissement, stratégies d'étude, et motivation intrinsèque: présentation d'un domaine de recherche et validation française de l' échelle d'Elliot et McGregor (2001) [Achievement goals, study strategies, and intrinsic motivation: presenting a domain of research and the French validation of Elliot and McGregor's (2001) scale]. L'Année Psychologique, 105, 105-131. doi:10.3406/psy.2005.3821.

Darnon, C., Butera, F., Mugny, G., Quiamzade, A., \& Hulleman, C. S. (2009a). “Too complex for me!” Why do performance-approach and performance-avoidance goals predict exam performance? European Journal of Psychology of Education, 24(4), 423-434. doi:10.1007/BF03178759. 
Darnon, C., Dompnier, B., Delmas, F., Pulfrey, C., \& Butera, F. (2009b). Achievement goal promotion at university: social desirability and social utility of mastery and performance goals. Journal of Personality and Social Psychology, 96(1), 119-134. doi:10.1037/a0012824.

Darnon, C., Dompnier, B., \& Poortvliet, M. (2012). Achievement goals in educational contexts. A social psychology perspective. Social \& Personality Psychology Compass, 6(10), 760-771. doi:10.1111/j.17519004.2012.00457.x.

Deemer, E. D. (2010). Achievement goals as predictors of research self-efficacy. Individual Differences Research, $8(4), 229-238$.

Delandshere, G. (2001). Implicit theories, unexamined assumptions and the status quo of educational assessment. Assessment in Education: Principles, Policy \& Practice, 8(2), 113-133. doi:10.1080/09695940123828.

Derks, B., van Laar, C., \& Ellemers, N. (2006). Striving for success in outgroup settings: effects of contextually emphasizing ingroup dimensions on stigmatized group members? Social identity and performance styles. Personality and Social Psychology Bulletin, 32(5), 576-588. doi:10.1177/0146167205283336.

Dinger, F. C., \& Dickhäuser, O. (2013). Does implicit theory of intelligence cause achievement goals? Evidence from an experimental study. International Journal of Educational Research, 61, 38-47. doi:10.1016/j.ijer.2013.03.008.

Dornbusch, S. M., Glasgow, K. L., \& Lin, I. C. (1996). The social structure of schooling. Annual Review of Psychology, 47, 401-429. doi:10.1146/annurev.psych.47.1.401.

Durik, A. M., Lovejoy, C. M., \& Johnson, S. J. (2009). A longitudinal study of achievement goals for college in general: predicting cumulative GPA and diversity in course selection. Contemporary Educational Psychology, 34(2), 113-119.

Duru-Bellat, M. (2006). L'inflation scolaire. Les désillusions de la méritocratie [The school inflation. Disillusions of meritocracy]. Paris: Seuil.

Dweck, C. S. (1986). Motivational processes affecting learning. American Psychologist, 41(10), 1040-1048. doi:10.1037/0003-066X.41.10.1040.

Ellemers, N., Van Knippenberg, A., de Vries, N., \& Wilke, H. (1988). Social identification and permeability of group boundaries. European Journal of Social Psychology, 18(6), 497-513. doi:10.1002/ejsp.2420180604.

Elliot, A. J. (1999). Approach and avoidance motivation and achievement goals. Educational Psychologist, 34(3), 169-189. doi:10.1207/s15326985ep3403_3.

Elliot, A. J., \& Church, M. A. (1997). A hierarchical model of approach and avoidance achievement motivation. Journal of Personality and Social Psychology, 72(1), 218-232. doi:10.1037/0022-3514.72.1.218.

Elliot, A. J., \& Harackiewicz, J. M. (1996). Approach and avoidance achievement goals and intrinsic motivation: a mediational analysis. Journal of Personality and Social Psychology, 70(3), 461-475. doi:10.1037/00223514.70.3.461.

Elliot, A. J., \& McGregor, H. A. (2001). A $2 \times 2$ achievement goal framework. Journal of Personality and Social Psychology, 80(3), 501-519. doi:10.1037/0022-3514.80.3.501.

Elliot, A. J., \& Murayama, K. (2008). On the measurement of achievement goals: critique, illustration, and application. Journal of Educational Psychology, 100(3), 613-628. doi:10.1037/0022-0663.100.3.613.

Elliot, A. J., Murayama, K., \& Pekrun, R. (2011). A $3 \times 2$ achievement goal model. Journal of Educational Psychology, 103(3), 632-648. doi:10.1037/a0023952. 
Elliot, A. J., \& Reis, H. T. (2003). Attachment and exploration in adulthood. Journal of Personality and Social Psychology, 85(2), 317-331. doi:10.1037/0022-3514.85.2.317.

Elliot, A. J., \& Thrash, T. M. (2002). Approach-avoidance motivation in personality: approach and avoidance temperaments and goals. Journal of Personality and Social

Psychology, 82(5), 804-818. doi:10.1037/0022-3514.82.5.804.

Elliot, A. J., \& Thrash, T. M. (2010). Approach and avoidance temperament as basic dimensions of personality. Journal of Personality, 78(3), 865-906. doi:10.1111/j.1467-6494.2010.00636.x.

Fiske, S. T. (2010). Interpersonal stratification: status, power, and subordination. In S. T. Fiske, D. T. Gilbert, \& G. Lindzey (Eds.), Handbook of social psychology (5th ed., Vol. 2, pp. 941-982). Hoboken, NJ: John Wiley \& Sons Inc.

Fiske, S. T., \& Markus, H. R. (2012). Facing social class. How societal rank influences interaction. New York: Russell Sage Foundation.

Gallo, L. C., de Los Monteros, K. E., \& Shivpuri, S. (2009). Socioeconomic status and health: what is the role of reserve capacity? Current Directions in Psychological Science, 18(5), 269-274.

Grieve, P. G., \& Hogg, M. A. (1999). Subjective uncertainty and intergroup discrimination in the minimal group situation. Personality and Social Psychology Bulletin, 25(8), 926-940. doi:10.1177/01461672992511002.

Guinote, A. (2007a). Power and goal pursuit. Personality and Social Psychology Bulletin, 33(8), 1076-1087. doi:10.1177/0146167207301011.

Guinote, A. (2007b). Power affects basic cognition: increased attentional inhibition and flexibility. Journal of Experimental Social Psychology, 43(5), 685-697. doi:10.1016/j.jesp.2006.06.008.

Guinote, A. (2007c). Behaviour variability and the situated focus theory of power. European Review of Social Psychology, 18, 256-295. doi:10.1080/ 10463280701692813.

Guinote, A. (2008). Power and affordances: when the situation has more power over powerful than powerless individuals. Journal of Personality and Social Psychology, 95(2), 237-252. doi:10.1037/a0012518.

Harackiewicz, J. M., Barron, K. E., Pintrich, P. R., Elliot, A. J., \& Thrash, T. M. (2002). Revision of achievement goal theory: necessary and illuminating. Journal of Educational Psychology, 94(3), 638-645. doi:10.1.1.336/3981.

Harackiewicz, J. M., Barron, K. E., Tauer, J. M., \& Elliot, A. J. (2002). Predicting success in college: a longitudinal study of achievement goals and ability measures as predictors of interest and performance from freshman year through graduation. Journal of Educational Psychology, 94(3), 562-575. doi:10.1037/00220663.94.3.562.

Harackiewicz, J. M., Canning, E. A., Tibbetts, Y., Giffen, C. J., Blair, S. S., Rouse, D. I., et al. (2014). Closing the social class achievement gap for first-generation students in undergraduate biology. Journal of Educational Psychology, 106(2), 375-389. http://dx.doi.org/10.1037/a0034679.

Howell, A. J., \& Buro, K. (2009). Implicit beliefs, achievement goals, and procrastination: a mediational analysis. Learning and Individual Differences, 19(1), 151-154. doi:10.1016/j.lindif.2008.08.006.

Hsieh, P., Sullivan, J. R., \& Guerra, N. S. (2007). A closer look at college students: self-efficacy and goal orientation. Journal of Advanced Academics, 18(3), 454-476. doi:10.4219/jaa-2007-500.

Huang, C. (2012). Discriminant and criterion-related validity of achievement goals in predicting academic achievement: a meta-analysis. Journal of Educational Psychology, 104(1), 48-73. doi:10.1037/a0026223. 
Hulleman, C. S., Schrager, S. M., Bodmann, S. M., \& Harackiewicz, J. M. (2010). A meta-analytic review of achievement goal measures: different labels for the same constructs or different constructs with similar labels? Psychology Bulletin, 136(3), 422-449. doi:10.1037/a0018947.

Iyer, A., Jetten, J., Tsivrikos, D., Postmes, T., \& Haslam, S. A. (2009). The more (and the more compatible) the merrier: multiple group memberships and identity compatibility as predictors of adjustment after life transitions. British Journal of Social Psychology, 48(4), 707-733. doi:10.1348/014466608X397628.

Jenkins, S. R., Belanger, A., Connally, M. L., Boals, A., \& Durón, K. M. (2013). First-generation undergraduate students' social support, depression, and life satisfaction. Journal of College Counseling, 16(2), 129-142. doi:10.1002/j.2161-1882.2013.00032.x.

Jetten, J., Iyer, A., Tsivrikos, D., \& Young, B. M. (2008). When is individual mobility costly? The role of economic and social identity factors. European Journal of Social Psychology, 38(5), 866-879. doi:10.1002/ejsp.471.

Johnson, S. E., Richeson, J. A., \& Finkel, E. J. (2011). Middle class and marginal? Socioeconomic status, stigma, and self-regulation at an elite university. Journal of Personal and Social Psychology, 100(5), 838-852. doi:10.1037/a0021956.

Jost, J. T., Banaji, M. R., \& Nosek, B. A. (2004). A decade of system justification theory: accumulated evidence of conscious and unconscious bolstering of the status quo. Political Psychology, 25(6), 881-919. doi:10.1111/j.1467-9221.2004.00402.x.

Jost, J. T., \& Hunyady, O. (2005). Antecedents and consequences of system-justifying ideologies. Current Directions in Psychological Science, 14(5), 260-265. doi:10.1111/ j.0963-7214.2005.00377.x.

Jost, J. T., Kay, A. C., \& Thorisdottir, H. (2009). Social and psychological bases of ideology and system justification. New York: Oxford University Press.

Kraus, M. W., Piff, P. K., Mendoza-Denton, R., Rheinschmidt, M. L., \& Keltner, D. (2012). Social class, solipsism, and contextualism: how the rich are different from the poor. Psychological Review, 119(3), 546-572. doi: $10.1037 / \mathrm{a} 0028756$.

Kuncel, N. R., Credé, M., \& Thomas, L. L. (2005). The validity of self-reported grade point averages, class ranks, and test scores: a meta-analysis and review of the literature. Review of Educational Research, 75(1), 6382. doi:10.3102/ 00346543075001063.

Lee, E. M., \& Kramer, R. (2013). Out with the old, in with the new? Habitus and social mobility at selective colleges. Sociology of Education, 86(1), 18-35. doi:10.1177/ 0038040712445519.

Liberatos, P., Link, B. G., \& Kelsey, J. L. (1988). The measurement of social class in epidemiology. Epidemiologic Reviews, 10, 87-121.

Maas, C. J. M., \& Hox, J. J. (2004). Robustness issues in multilevel regression analysis. Statistica Neerlandica, 58, 127-137. doi:10.1046/j.0039-0402.2003.00252.x. McGregor, H. A., \& Elliot, A. J. (2002). Achievement goals as predictors of achievement-relevant processes prior to task engagement. Journal of Educational Psychology, 94(2), 381-395. doi:10.1037/0022-0663.94.2.381.

Murayama, K., \& Elliot, A. J. (2012). The competition-performance relation: a meta-analytic review and test of the opposing processes model of competition and performance. Psychological Bulletin, 138, 1035-1070. doi:10.1037/ a0028324.

Nicholls, J. G. (1984). Achievement motivation: conceptions of ability, subjective experience, task choice, and performance. Psychological Review, 91(3), 328-346. doi:10.1037/0033-295X.91.3.328. 
Organisation for Economic Co-operation and Development (2012). Education at a glance 2012: OECD indicators. OECD Publishing. <http://dx.doi.org/10.1787/eag-2012-en>.

Ostrove, J. M., \& Long, S. M. (2007). Social class and belonging: implications for college adjustment. Review of Higher Education: Journal of the Association for the Study of Higher Education, 30(4), 363-389. doi:10.1353/rhe.2007.0028.

Payne, S. C., Youngcourt, S. S., \& Beaubien, J. M. (2007). A meta-analytic examination of the goal orientation nomological net. Journal of Applied Psychology, 92(1), 128-150. doi:10.1037/0021-9010.92.1.128.

Pekrun, R., Elliot, A. J., \& Maier, M. A. (2006). Achievement goals and discrete achievement emotions: a theoretical model and prospective test. Journal of Educational Psychology, 98(3), 583-597. doi:10.1037/0022-0663.98.3.583.

Pekrun, R., Elliot, A. J., \& Maier, M. A. (2009). Achievement goals and achievement emotions: testing a model of their joint relations with academic performance. Journal of Educational Psychology, 101(1), 115-135. doi: $10.1037 / \mathrm{a} 0013383$.

Pulfrey, C., Buchs, C., \& Butera, F. (2011). Why grades engender performance-avoidance goals: the mediating role of autonomous motivation. Journal of Educational Psychology, 103(3), 683-700. doi: $10.1037 / \mathrm{a} 0023911$.

Putwain, D. W., Larkin, D., \& Sander, P. (2013). A reciprocal model of achievement goals and learning related emotions in the first year of undergraduate study. Contemporary Educational Psychology, 38(4), 361-374. doi:10.1016/ j.cedpsych.2013.07.003.

Ramos-Sánchez, L., \& Nichols, L. (2007). Self-efficacy of first-generation and non-first-generation college students: The relationship with academic performance and college adjustment. Journal of College Counseling, 10(1), 6-18. http:// dx.doi.org/10.1002/j.2161-1882.2007.tb00002.x.

Reay, D., Crozier, G., \& Clayton, J. (2009). 'Strangers in paradise'?: working-class students in elite universities. Sociology, 43(6), 1103-1121. doi:10.1177/ 0038038509345700.

Russell, A. M., \& Fiske, S. T. (2010). Power and social perception. In A. Guinote \& T. K. Vescio (Eds.), The social psychology of power (pp. 231-250). New York: Guilford Press.

Ryan, K. E., \& Ryan, A. M. (2005). Psychological processes underlying stereotype threat and standardized math test performance. Educational Psychologist, 40(1), 53-63. doi:10.1207/s15326985ep4001_4.

Sackett, P. R., Kuncel, N. R., Arneson, J. J., Cooper, S. R., \& Waters, S. D. (2009). Does socioeconomic status explain the relationship between admissions tests and post-secondary academic performance? Psychology Bulletin, 135(1), 1-22. doi:10.1037/a0013978.

Scheepers, D., \& Ellemers, N. (2005). When the pressure is up: the assessment of social identity threat in low and high status groups. Journal of Experimental Social Psychology, 41(2), 192-200. doi:10.1016/j.jesp.2004.06.002.

Senko, C., \& Harackiewicz, J. M. (2005). Regulation of achievement goals: the role of competence feedback. Journal of Educational Psychology, 97(3), 320-336. doi:10.1037/0022-0663.97.3.320.

Sidanius, J., \& Pratto, F. (1999). Social dominance: An intergroup theory of social hierarchy and oppression. New York: Cambridge University Press.

Sirin, S. R. (2005). Socioeconomic status and academic achievement: a meta-analytic review of research. Review of Educational Research, 75(3), 417-453. doi:10.3102/ 00346543075003417. 
Slabu, L., \& Guinote, A. (2010). Getting what you want: power increases the accessibility of active goals. Journal of Experimental Social Psychology, 46(2), 344-349. doi:10.1016/j.jesp.2009.10.013.

Smeding, A., Darnon, C., Souchal, C., Toczek-Capelle, M. C., \& Butera, F. (2013). Reducing the socio-economic status achievement gap at university by promoting mastery-oriented assessment. PLoS ONE, 8(8), e71678. doi:10.1371/journal.pone.0071678.

Smith, J. L. (2004). Understanding the process of stereotype threat: a review of mediational variables and new performance goal directions. Educational Psychology Review, 16(3), 177-206. doi:10.1023/B:EDPR.0000034020.20317.89.

Smith, J. L., Sansone, C., \& White, P. H. (2007). The stereotyped task engagement process: the role of interest and achievement motivation. Journal of Educational Psychology, 99(1), 99-114. doi:10.1037/00220663.99.1.99.

Snibbe, A. C., \& Markus, H. R. (2005). You can't always get what you want: educational attainment, agency, and choice. Journal of Personality and Social Psychology, 88(4), 703-720. doi:10.1037/0022-3514.88.4.703.

Sommet, N., Darnon, C., Mugny, G., Quiamzade, A., Pulfrey, C., Dompnier, B., et al. (2014). Performance goals in conflictual social interactions: toward the distinction between two modes of relational conflict regulation. British Journal of Social Psychology, 53(1), 134-153. doi:10.1111/bjso.12015.

Spencer, B., \& Castano, E. (2007). Social class is dead. Long live social class! Stereotype threat among low socioeconomic status individuals. Social Justice Research, 20(4), 418-432. doi:10.1007/s11211-007-00477.

Ståhl, T., Van Laar, C., \& Ellemers, N. (2012). The role of prevention focus under stereotype threat: initial cognitive mobilization is followed by depletion. Journal of Personality and Social Psychology, 102(6), 1239-1251. doi:10.1037/ a0027678.

Stephens, N. M., Fryberg, S. A., Markus, H. R., Johnson, C. S., \& Covarrubias, R. (2012a). Unseen disadvantage: how American universities' focus on independence undermines the academic performance of firstgeneration college students. Journal of Personality and Social Psychology, 102(6), 1178-1197. doi: $10.1037 / \mathrm{a} 0027143$.

Stephens, N. M., Hamedani, M. G., \& Destin, M. (2014). Closing the social-class achievement gap: a differenceeducation intervention improves first-generation students' academic performance and all students' college transition. Psychological Science, 25(4), 943-953.

Stephens, N. M., Markus, H. R., \& Fryberg, S. A. (2012b). Social class disparities in health and education: reducing inequality by applying a sociocultural self model of behavior. Psychological Review, 119(4), 723-744. doi:10.1037/a0029028.

Stephens, N. M., Townsend, S. S. M., Markus, H. R., \& Phillips, L. T. (2012c). A cultural mismatch: independent cultural norms produce greater increases in cortisol and more negative emotions among first-generation college students. Journal of Experimental Social Psychology, 48(6), 1389-1393. doi:10.1016/j.jesp.2012.07.008.

Turner, J. C., Midgley, C., Meyer, D. K., Gheen, M., Anderman, E. M., Kang, Y., et al. (2002). The classroom environment and students' reports of avoidance strategies in mathematics: a multimethod study. Journal of Educational Psychology, 94(1), 88-106. doi:10.1037/0022-0663.94.1.88. 
Van Laar, C., Bleeker, D., Ellemers, N., \& Meijer, E. (2014). Ingroup and outgroup support for upward mobility: divergent responses to ingroup identification in low status groups. European Journal of Social Psychology, 44(6), 563-577. http://dx.doi.org/10.1002/ejsp.2046.

Van Laar, C., Derks, B., Ellemers, N., \& Bleeker, D. (2010). Valuing social identity: consequences for motivation and performance in low-status groups. Journal of Social Issues, 66(3), 602-617. doi:10.1111/j.15404560.2010.01665.x.

Van Laar, C., \& Sidanius, J. (2001). Social status and the academic achievement gap: a social dominance perspective. Social Psychology of Education, 4(3-4), 235-258. doi:10.1023/A:1011302418327.

Van Yperen, N. W. (2006). A novel approach to assessing achievement goals in the context of the $2 \times 2$ framework: identifying distinct profiles of individuals with different dominant achievement goals. Personality and Social Psychology Bulletin, 32(11), 1432-1445. doi:10.1177/0146167206292093.

Van Yperen, N. W., Blaga, M., \& Postmes, T. (2014). A meta-analysis of self-reported achievement goals and nonself-report performance across three achievement domains (work, sports, and education). PLoS ONE, 9(4), e93594. doi:10.1371/ journal.pone.0093594.

Van Yperen, N. W., Hamstra, M. R. W., \& Van der Klauw, M. (2011). To win, or not to lose, at any cost: the impact of achievement goals on cheating. British Journal of Management, 22, S5-S15. doi:10.1111/j.14678551.2010.00702.x

Walton, G. M., \& Cohen, G. L. (2007). A question of belonging: race, social fit, and achievement. Journal of Personality and Social Psychology, 92(1), 82-96. doi:10.1037/0022-3514.92.1.82.

Warner, R., Hornsey, M. J., \& Jetten, J. (2007). Why minority group members resent impostors. European Journal of Social Psychology, 37(1), 1-17. doi:10.1002/ejsp.332. Williams, J. C. (2012). The class culture gap. In S. Fiske \& H. R. Markus (Eds.), Facing social class: How societal rank influences interaction (pp. 39-58). New York: Russell Sage Foundation.

Wohn, D. Y., Ellison, N. B., Khan, M. L., Fewins-Bliss, R., \& Gray, R. (2013). The role of social media in shaping first-generation high school students' college aspirations: a social capital lens. Computers \& Education, 63, $424-436$.

Zusho, A., \& Clayton, K. (2011). Culturalizing achievement goal theory and research. Educational Psychologist, 46(4), 239-260. doi:10.1080/00461520.2011.614526. Zusho, A., \& Njoku, H. (2007). Culture and motivation to learn. In F. Salili \& R. Hoosain (Eds.), Culture, motivation and learning (pp. 91-113). Information Age Publishing.

Zusho, A., Pintrich, P. R., \& Cortina, K. S. (2005). Motives, goals, and adaptive patterns of performance in Asian American and Anglo American students. Learning and Individual Differences, 15(2), 141-158. doi:10.1016/j.lindif.2004.11.003.

How to cite:

Jury, M., Smeding, A., Court, M, \& Darnon, C. (2015). When first-generation students succeed at university: On the link between social class, academic performance, and performance-avoidance goals. Contemporary Educational Psychology, 41, 25-36. doi:10.1016/j.cedpsych.2014.11.001 